\title{
The development of organization of living things module through the use of mnemonic and mind mapping method using brain-based learning approach for junior high school natural science learning in coastal areas

\author{
Jekti Prihatin ${ }^{1, *}$, Nina Naurah ${ }^{2}$, Kamalia Fikri ${ }^{3}$ \\ Department of Biology Education, Faculty of Teacher Training and Education, Universitas Jember, \\ Indonesia \\ 1 jekti.fkip@unej.ac.id *, ${ }^{2}$ ninanaurah9@gmail.com, ${ }^{3}$ kamalia.fikri@gmail.com \\ * Corresponding author
}

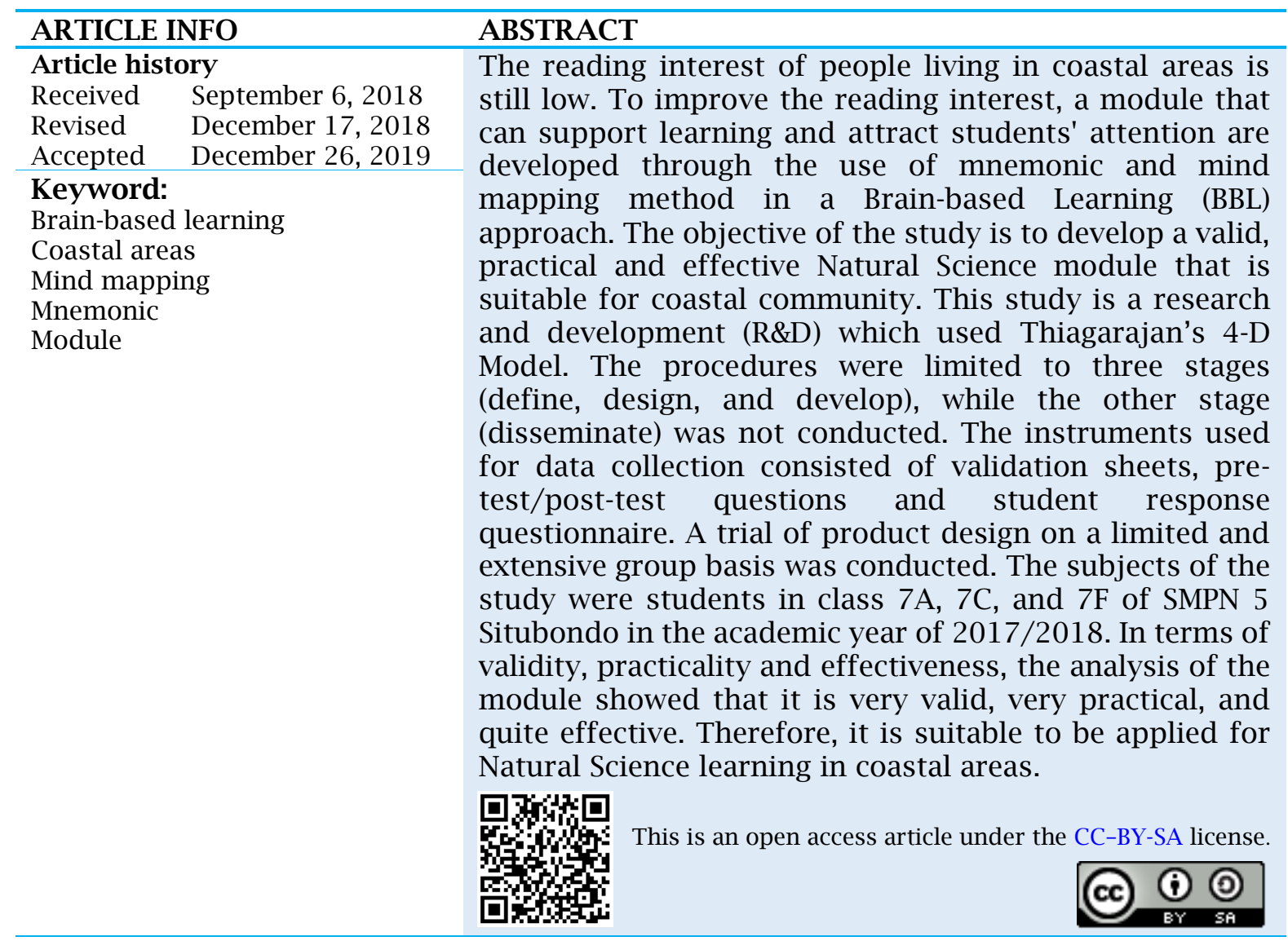

\section{Introduction}

The majority of the Indonesian population living in coastal areas work as fishermen (Muflikhati, Hartoyo, Sumarwan, Fahrudin, \& Puspitawati, 2010). Coastal communities have a low level of education and are in a marginal position (Wasak, 2012). Based on the data from the Central Statistics Agency (BPS) of East Java, School Participation Rate (APS) for junior high schools and senior high schools in 2014 for regencies in the Eastern Java coastal areas that include Lumajang, Jember, Banyuwangi, Situbondo and Probolinggo was $94.15 \%$ and $63.88 \%$ respectively. In 2015, the junior high school participation rate decreased to $93.39 \%$, whereas the senior high school participation rate fell to $60.31 \%$. This figure showed a decline of learning interest from junior high school to senior high school by $30.27 \%$ in 2014 and 
32.97\% in 2015 (BPS-Jatim, 2017). The low interest in learning was caused by the large amount of time spent on helping parents who work as fishermen and on other activities to improve family's welfare (Wasak, 2012). Interest in learning that is indicated by the level of schooling also has a positive correlation with interest in reading.

The mapping of reading interest of junior high school students in the age range of 13-15 years in Indonesia, especially in the provinces of South Sulawesi, Riau and South Kalimantan showed a moderate figure. Students only spend around 1-2 hours/day for reading, which equals to $45 \%$. Reading habit is considered high if the activity is conducted more than 3 hours/day (Saleh et al., 2007). Likewise, the result of interview with grade 7 Natural Science teachers at 3 public junior high schools in Situbondo provided the same data, 1-2 hours/day. Reading interest, especially in Natural Science subject in junior high schools needs to be improved because Natural Science subject is considered difficult (Vikagustanti, Sudarmin, \& Pamelasari, 2014). Interest in reading can be increased in various ways, for example by using interesting teaching materials that can also be used individually in accordance to the pace of learning. For this reason, it is necessary to develop teaching materials in the form of modules.

Modules are printed teaching materials that are equipped with instructions for independent learning (Putri, Ramli, \& Suciati, 2017). The modules that are integrated with fun learning strategies and methods can increase students' curiosity and understanding. Some module development studies based on specific learning approaches have been carried out, including the Level of Inquiry-based biology module (Putri et al., 2017), Science, Environment, Technology, and Societybased Natural Science Module (Budi, Sunarno, \& Sugiyarto, 2018), Natural Science module based on Science, Technology, Engineering, and Mathematics/STEM (Kasim \& Ahmad, 2018). The aforementioned modules that have been developed have its own strengths for certain purposes. The weakness of these modules is that there are no modules that aim to optimize the function of the right and left brain. Modules that can optimize the brain function can be designed using a Brain-based Learning (BBL) approach.
The BBL module has a unique character, that is the presentation of the material focuses on strategies to optimize the right and left brain. According to Caine and Caine (1990), the BBL approach has 12 basic principles: (1) The brain is a parallel process, (2) learning involves the whole physiology of the body, (3) the search for meaning is innate, (4) the search for meaning takes place through the formation of patterns , (5) involvement of emotions is important in pattern formation, (6) the brain/ mind processes information partially or wholly in a simultaneous manner, (7) learning involves attention focusing and peripheral perceptions, (8) learning always includes conscious and unconscious processes, (9) We have two types of memory, namely a spatial memory system and a set of systems for memorization, (10) the brain understands and remembers well when facts and skills are embedded in natural spatial memory, (11) learning can be enhanced through challenges and inhibited through threats , (12) each brain is unique.

The technical implementation of BBL basically uses fun, light, collaborative, active learning techniques, and stimulates curiosity. Therefore, BBL printed modules will be packaged as attractive as possible using mnemonic and mind mapping.

Mind mapping can integrate and balance the function of the two hemispheres of the brain because mind mapping uses images, symbols, colors, and illustrations. The symbols used in the notes will make it easier for students to remember the material being studied (Hobri, 2009). Despite the strengths of the mind mapping method, this method still has weaknesses. For instance, only active students are involved in learning. In addition, the large number of mind mapping variations created by students makes teachers overwhelmed in correcting the concepts that students have understood (Kurniawati, Suliyanah, \& Qosyim, 2013).

The weakness of mind mapping can be overcome by integrating mnemonic method that encourages all students to be active. Furthermore, students can get more detailed information in learning. Mnemonic is effective and helps students succeed in school. This is indicated by a research conducted by Halim (2012), the research results showed that students who experienced learning using mnemonic demonstrated an increase in long-term 
memory by $67.81 \%$ with grades ranging from 61 to 80 . Among the advantages of mnemonic method are: 1) it is fun; 2) it can improve memory; and 3) it encourages students to be more creative. The weakness of the mnemonic method is that it does not give meaning to students who are not accustomed to meaningful learning because it requires high imagination and creativity so that the material can be understood and remembered for a long period of time (Hasyim \& Sudjono, 2015).

A good developed product should meet valid, effective, and practical criteria (Akker, Bannan, Kelly, Nieveen, \& Plomp, 2013). Therefore, the purpose of this study is to obtain a valid, effective, and practical Organization of Living Things module using mnemonic and mind mapping method in BBL.

\section{Method}

This research employed Thiagarajan's 4D model for development research, but only applied the three stages (define, design, and develop). The fourth stage (disseminate) was not carried out because the purpose of this study is only to produce a valid, practical, and effective module. The defining phase consisted of initial analysis, student analysis, task analysis, concept analysis, and formulation of learning objectives. The designing phase included test preparation, media selection, format selection, and initial design. The development phase comprised: a) validation of the module by experts followed by revisions, b) limited trial, and c) extensive trial. Product design trial was conducted at SMPN 5 Situbondo. The Organization of Living Things module being developed for grade 7 at least should meet good criteria for validity, practicality, and effectiveness with medium $\mathrm{N}$-gain value.

The validity of the module was measured based on validation results by 3 expert validators and 1 user. The expert validators consisted of material expert lecturer, media expert lecturer, and development expert lecturer, while the users were represented by 1 Natural Science teacher. The practicality of the module was measured using a student response questionnaire which was distributed to 9 students in class 7F of SMPN 5 Situbondo. The module effectiveness was measured using cognitive and psychomotor learning outcomes of 32 students in class $7 \mathrm{~A}$ representing the control class and 26 students in class $7 \mathrm{C}$ as an experimental class. Student learning retention was measured 2 weeks after the post-test. The results of calculation obtained from quantitative data were then converted into qualitative data which can be seen in Table 1 and Table 2.

Table 1. Validation criteria of module

\begin{tabular}{ll}
\hline Percentage range (\%) & \multicolumn{1}{c}{ Category } \\
\hline $81.25 \leq \mathrm{x} \leq 100$ & Very valid \\
$62.5 \leq \mathrm{x}<81.25$ & Valid \\
$62.5 \leq \mathrm{x}<81.25$ & Less Valid \\
$25 \leq \mathrm{x}<43.75$ & Invalid \\
\hline
\end{tabular}

Table 2. Practicality criteria of module

\begin{tabular}{ll}
\hline Percentage range (\%) & \multicolumn{1}{c}{ Category } \\
\hline $\mathrm{p} \geq 85$ & Very good \\
$70 \leq \mathrm{p}<85$ & Good \\
$50 \leq \mathrm{p}<70$ & Fair \\
$\mathrm{p}<50$ & Not good \\
\hline
\end{tabular}

The following normalized gain formula was used to analyze improvement in student learning outcomes

$$
N-\text { gain }=\frac{\text { Spost }- \text { Spre }}{100-\text { Spre }}
$$

(Richard R Hake, 2002)

Description:

$N$-gain $=$ Normalized gain

Spre = average pre-test score

Spost $=$ average post-test score

The obtained normalized gain criteria can be seen in Table 3 .

Table 3. $N$-gain result criteria

\begin{tabular}{ll}
\multicolumn{1}{c}{ Coefficient score } & \multicolumn{1}{c}{ Category } \\
\hline Normalized-gain $\geq 0.70$ & High \\
$0.30 \leq$ Normalized-gain $<0.70$ & Medium \\
Normalized-gain $<0.30$ & Low \\
\hline & (R. R. Hake, 1999)
\end{tabular}

\section{Results and Discussion}

The defining stage included 1) initial analysis, 2) student analysis, 3) task analysis, 4) concept analysis, and 5) formulation of learning objectives. The stage was conducted by distributing questionnaires to 3 junior high school teachers and 27 students in the coastal areas (SMP Negeri 3 Panarukan, SMP Negeri 4 Situbondo and SMP Negeri 5 Situbondo) to analyze problems or needs that are necessary to design the module.

Based on the results of the initial analysis, it can be seen that $66.7 \%$ of the 
Natural Science teachers use textbooks and worksheets, and the learning approaches used are Problem-Based Learning (33.3\%) and Scientific Approach (66.7\%). However, none of the teachers know about BBL approach, so it has never been applied in learning. The percentage of the teachers who have knowledge about mnemonic and mind mapping is $33.3 \%$. In addition, the student analysis through the test on previous materials and interview with teachers and students indicated that the majority of the cognitive learning results (73\%) is still under 70, the Minimum Passing Grade Criteria (KKM). Based on the concept and task analysis, the material about organization of living things is included in Basic Competence (KD) 3.6. The competence requires students to identify the organization of the living things from cell until organism and the main compositions that constitute cell. The 3.6 Basic Competence was then formulated into indicators and learning objectives, concept mapping, and tasks that students must do.

The designing process consisted of three stages, namely the preparation of test, media selection, format selection, and initial design. The same questions consisting of 25 multiple choice questions and 5 description questions were used in the pre-test and post-test. The media chosen to be developed in this research is a module using mnemonic and mind mapping that are integrated into BBL approach.

The development stage consisted of several steps including module validation by experts which was followed by: a) revision, b) limited trial and c) extensive trial. The validation was conducted by distributing validation sheet to validators consisting of material, development, and media experts and users. The validation sheet is used to collect assessment on the developed teaching material. This validation is related to the question items that will be asked to students. The validation of the content and the measurability of the objectives were carried out by experts involving teachers and lecturers.

The first validation was conducted by the material expert validator, covering aspects such as content, presentation and language. From the validation it is obtained that the average validity is $78.9 \%$. It means that the module is valid and a slight revision is required before it is used in learning activities. Material expert validator also provided recommendation and comment for module improvement. It was recommended that more careful attention is paid to material writing because there are many writing errors. The sources of the literature are also not included so that the source of each sub material is unknown.

The second validation which consisted of three stages (define, design, and develop) was carried out by the development expert. The results of the assessment by the development expert validator showed that the average percentage is $81.3 \%$ (categorized as very valid). Thus, the product design can be used for learning activities in the class. Furthermore, the development expert validator did not give any recommendation or comment for module improvement.

The third validation was carried out by media expert and covered eligibility in aspects such as presentation, language and graphic. Based on the evaluation of the media expert validator, it can be seen that the average percentage is $88.3 \%$ and categorized as very valid. The media expert validator also provided recommendation and comment. It was suggested that the cover needs revision because it is not sufficiently interesting. This is not in line with Tur and Marín (2014) who state that interesting and innovative media will attract more positive response from students and will influence students' understanding of the material being taught. Based on the comment from media expert, revision was made to the module cover (Figure 1).

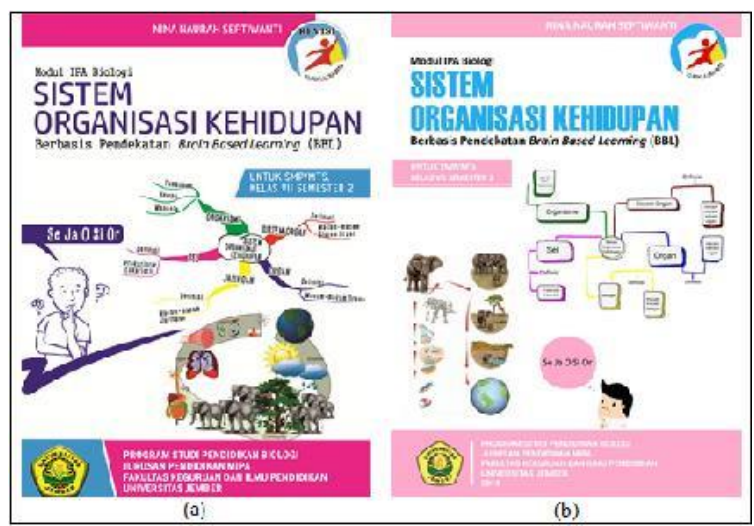

Figure 1. Module Cover (a) initial design dan (b) revised design

The fourth validation was performed by the user who assessed the function and benefits, the appropriateness of presentation, language, and graphics. The assessment by user validator showed an average percentage of $93.3 \%$ and was 
categorized as very valid. The recommendation and comment provided by user validator is the need to improve writing on the concept mapping. The overall validation results obtained from four validators namely material expert, development expert, media expert and users reaches an average percentage of $85.5 \%$, meaning that it is very valid. Based on this assessment result, the module can be used for further test namely practicality and effectiveness tests which are carried out through extensive test (learning activities in the classroom).
The next step was conducting a limited trial through the use of questionnaire to obtain student response. The participants were 9 students of grade 7 at SMPN 5 Situbondo who were selected based on academic ability (high, medium and low level). Three students were selected to represent each category. These nine students were asked to fill in the questionnaire that shows their response toward the draft of the module. The response is presented in Table 4.

Table 4.Analysis result of student response toward the module

\begin{tabular}{ccc}
\hline Aspect & Average (\%) & Interpretation \\
\hline Readibility & 94.4 & Very good \\
Clarity & 84.4 & Very good \\
Attractiveness of design and guidelines & 92.6 & Very good \\
Interest in the use of module for learning & 77.8 & Good \\
\hline Average & 87.3 & Very good \\
\hline
\end{tabular}

It can be seen in Table 4 that the average student response toward the developed module in the limited test is $87.3 \%$. It means that the module has reached a very good category. It can be said that the module is very practical. Nevertheless, the attractiveness of the module is increased by adding variations on 'Let's Practice' using Crosswords, Finding Hidden Words and making practice questions with answer choices using colored pictures. Based on the assessment from the students, the module that has been improved is ready to be tested in the learning process in a class (field test).
The effectiveness of the module was tested through quasi experiment using control class and experimental class. The effectiveness value shows a successful application of the developed module. The results that are close to the goals that have been determined show a higher level of effectiveness. The effectiveness of the module on learning outcomes can be seen through the pre-test and post-test values that were analyzed using Anacova and Ngain. The effectiveness of the module to enhance learning outcomes based on the field test can be seen in Table 5 .

Table 5. Student cognitive learning outcomes

\begin{tabular}{lcllll}
\hline \multicolumn{1}{c}{ Class } & $\begin{array}{c}\text { Number of } \\
\text { students }\end{array}$ & Average Pre-test & Average Post-test & $\begin{array}{l}\text { Average } \\
\text { difference }\end{array}$ & $\boldsymbol{N}$-gain \\
\hline Experimental & 26 & $17.88 \pm 13.67$ & $59.77 \pm 13.30$ & 41.89 & 0.5 \\
Control & 32 & $18.84 \pm 5.83$ & $29.69 \pm 10.26$ & 10.85 & 0.1 \\
\hline
\end{tabular}

Based on the cognitive learning outcomes data in Table 5, the $\mathrm{N}$-gain result in the experimental class is 0.50 , in medium category. Data were then analyzed using Anakova with the help of SPSS software with a probability value of $0.000(\mathrm{P}<0.05)$. The results indicated that the application of the module using mnemonic and mind mapping in BBL affects the student cognitive learning outcomes. Thus, the results of Anakova and $\mathrm{N}$-gain analysis show that the module using mnemonic and mind mapping in BBL is effective.

The improved cognitive aspect through the use of the module was caused by, among other things, the application of mnemonic technique. For example, each student was asked to make an acronym from the material being studied. The acronyms made by students varied, thus it was sometimes difficult to memorize. However, after repeating the activity students were able to make acronyms that are easy to remember. Making acronyms made students energized and excited. In addition, students were instructed to make abbreviations from the material that they understood in accordance to students' imagination. This activity allowed students to remember the material more easily in a longer period of time. This result is the same as Halim (2012) research which found that students who experienced 
learning using the mnemonic method demonstrated an increase in the long-term memory by $67.81 \%$ with grades ranging from 61 to 80 . Mocko, Lesser, Wagler, and Francis (2017), state further that mnemonic can reduce anxiety in studying and taking statistical test. This is very much in line with one of the BBL principles stating that learning should avoid threats. Students who are excited are associated with the increased adrenaline due to challenges. Students' happiness when they see the acronyms made by their peers is related to the increase in dopamine hormone and the decrease in stress hormone, cortisol (Arita, 2016). Creativity and emotions are the function of the right brain (Corballis, 2014).

For the next improvement of the module, it is necessary to add mnemonic in the form of songs that are well known among students in the coastal areas, as Lesser (2011a) did with twinkle-twinkle little star song. Lesser (2011b) adds that mnemonic is not intended to replace highlevel thinking or conceptual understanding, but only to stimulate students to remember low-level facts more easily and summarize important and conceptual memorization. The following is an example of the mnemonic in the module (Figure 2).

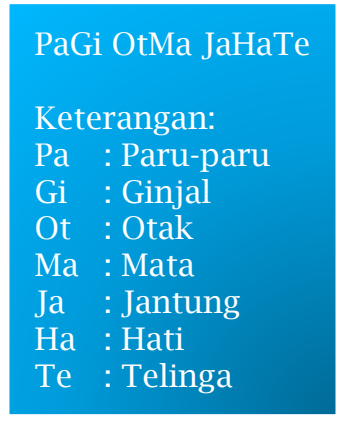

(a)

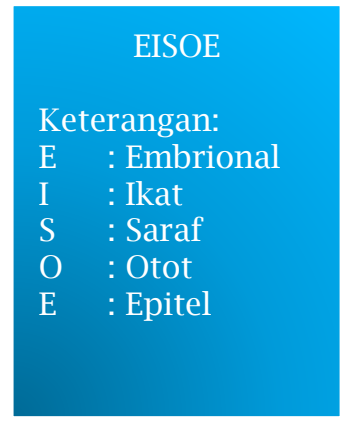

(b)
Figure 2. mnemonic acrostics (a) and mnemonic acronyms (b)

Data on psychomotor learning outcomes from the two practicums performed in 'Let's Experiment' module can be seen in Table 6. The psychomotor indicators taken are the ability to prepare practicum tools and materials, the ability to do practicum according to procedures and the assessment of practicum report.

Table 6. Student psychomotor learning outcomes

\begin{tabular}{lccc}
\hline \multicolumn{1}{c}{ Class } & Number of students & Average & Difference \\
\hline Experimental & 26 & $88.80 \pm 7.92$ & 20.8 \\
Control & 32 & $68.00 \pm 7.72$ & \\
\hline
\end{tabular}

In the next stage, the psychomotor learning outcomes were analyzed using $t$ test and the probability value is 0.000 ( $\mathrm{P}$ $<0.05$ ). It shows that psychomotor ability between students who did practicum following instructions in the module (experimental class) and students who did practicum in conventional classes (control classes) differs significantly. The psychomotor ability of students who used the module is higher than students who did not, with a 20-point difference. The value of motoric skills is categorized as high. This is not surprising because students that come from coastal areas prefer physical activity.

The psychomotor ability increased because the content of the module contains directions for doing a practicum on 'Let's Experiment'. Therefore, students had to do the activity actively. The practicum has an accompanying effect such as promoting honest, responsible, and disciplined scientific attitude in doing and collecting assignments. Being open and honest is the fundamental attitude of coastal communities. Natural Science Practicum which was conducted as instructed in the module can accommodate students who have kinesthetic learning styles as the manifestation of the right brain function. One of the optimization of the functions of the brain in addition to visual and auditory aspects is kinesthetic.

Table 7. Analysis of t-test retention results

\begin{tabular}{lrrll}
\multicolumn{1}{c}{ Class } & $\boldsymbol{t}$ & $\mathbf{d b}$ & \multicolumn{1}{c}{ Average \pm SD } & Significance \\
\hline Control & 14.179 & 31 & $20.2 \pm 8.05$ & 0.000 \\
Experimental & 26.372 & 25 & $63 \pm 12.23$ & \\
\hline
\end{tabular}

Two weeks after the post-test, a retention test was performed. The results of the retention analysis of learning outcomes using the $t$ test can be seen in Table 7 . 
As can be seen in Table 7 , retention was analyzed using $t$ test and the probability value is $0.000(\mathrm{P}<0.05)$. It shows that the module using mnemonic and mind mapping method in BBL has a significant difference on student retention.

This condition is in accordance with similar research conducted by Lasmiyati and Harta (2014), the research showed that the learning module is effective for improving learning outcomes in terms of conceptual understanding. Widyaningrum, Sarwanto, and Karyanto (2013) state that module can improve student learning outcomes significantly. In this study, learning outcomes increased in each meeting because students have become accustomed to practicum method. Another reason the module can improve learning outcomes is that because it uses mnemonic and mind mapping method in Brain-Based Learning approach.

Mind mapping which is combined with mnemonic in the designed module was proven to make students more active and passionate in class discussions. The same result is shown in Wilson, Copeland Solas, and Guthrie-Dixon (2016) research, the research proved that the application of mind mapping as a form of visual learning makes students more responsive, motivated, and contributes positively to learning.

Another factor that caused an increase in learning outcomes besides mnemonic is that because students were asked to make a mind map for Organization of Living Things after having a discussion. The material on how to make a mind map is included in the module. Improved learning outcomes can be understood as a result of mind mapping which is one of the methods in BBL approach. Students are demanded to be creative in making a mind map of the material taught. Colors, images and shapes that students prefer are allowed to be used to create the framework of thinking so that students are better at remembering the material without memorizing too much to avoid excessive use of the brain. This method can balance the function of the right and left brain. Mind mapping is a method that helps unlock all potential to all directions so that children can remember well, learn faster and more efficiently and practise the whole picture. The following is an example of a mind map taken from the module Figure 3.

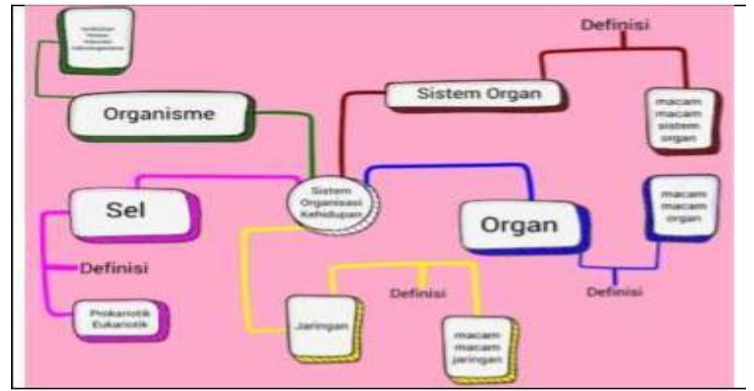

Figure 3. Mind map about living things hierarchy level

\section{Conclusion}

Based on the results and discussion, it can be concluded that the module that was designed using mnemonic and mind mapping method in BBL is categorized as very valid, with a validation value of $82.8 \%$ and $93.3 \%$ from expert validators and user validator respectively. In terms of practicality, the module is categorized as very good (87.3\%). The $\mathrm{N}$-gain value from the module effectiveness is 0.50 , meaning that it is effective.

\section{References}

Akker, J. van den, Bannan, B., Kelly, A. E., Nieveen, N., \& Plomp, T. (2013). Educational design research part a: An introduction (T. Plomp \& N. Nieveen, Eds.). Netherlands: SLO.

Arita, H. (2016). Teknik menghilangkan stress dari Otak: Serotonin dan air mata pengubah hidup (Faizal, Trans.). Jakarta: Gramedia Pustaka Utama.

BPS-Jatim. (2017). Angka partisipasi sekolah tahun 2015. Retrieved from https://jatim.bps.go.id/linkTabelSta tis/view/id/182

Budi, A. P. S., Sunarno, W., \& Sugiyarto. (2018). Natural science modules with SETS approach to improve students' critical thinking ability. Journal of Physics: Conference Series, 1022(1), 1-9. https://doi.org/10. 1088/1742-6596/1022/1/012015

Caine, R. N., \& Caine, G. (1990). Understanding a brain-based approach to learning and teaching. Educational Leadership., 66-70. Retrieved from https://pdfs. semanticscholar.org/8d58/b6af940 e0117fcd4f52ef7e73e16690261f5.p df 
Corballis, M. C. (2014). Left brain, right brain: Facts and fantasies. PLoS Biology, 12(1), 1-6. https://doi.org/ 10.1371/journal.pbio.1001767

Hake, R. R. (1999). Analyzing change/gain scores. Retrieved from https://www. physics.indiana.edu/ sdi/Analyzing Change-Gain.pdf

Hake, Richard R. (2002). Relationship of individual student normalized learning gains in mechanics with gender, high-school physics, and pretest scores on mathematics and Spatial Visualization. Physics Education Research Conference, 114. Retrieved from https://www. physics.indiana.edu/ hake/PERC20 02h-Hake.pdf

Halim, M. A. (2012). Keefektifan teknik mnemonic untuk meningkatkan memori jangka panjang dalam pembelajaran biologi pada siswa kelas VIII SMP Al-Islam 1 Surakarta (Universitas Sebelas Maret). Retrieved from https://digilib. uns.ac.id/dokumen/detail/28711/K eefektifan-teknik-mnemonic-untukmeningkatkan-memori-jangka-panja ng-dalam-pembelajaran-biologi-pa da-siswa-kelas-viii-smp-al-islam-1surakarta

Hasyim, M., \& Sudjono, M. J. E. (2015). Perbandingan hasil belajar matematika melalui eksperimentasi metode mind mapping dan metode mnemonic ditinjau dari tingkat kemampuan memori siswa. Jurnal Pendidikan Dan Pembelajaran Matematika, 1(1), 1-10. Retrieved from https://jurnal.stkippgritulung agung.ac.id/index.php/jp2m/article /view/189/72

Hobri. (2009). Model-model pembelajaran inovatif. Jember: Center For Society Studies.

Kasim, N. H., \& Ahmad, C. N. C. (2018). PROSTEM module: The development and validation. International Journal of Academic Research in Business and Social Sciences, 8(1), 728-739. https://doi.org/10.6007/IJARBSS/v 8-i1/3843

Kurniawati, A., Suliyanah, S., \& Qosyim, A. (2013). Pengembangan bahan ajar IPA terpadu tema letusan gunung berapi kelas VII di SMP Negeri 1 Kamal. Jurnal Pendidikan Sains E-
Pensa, 1(1), 42-46. Retrieved from https://jurnalmahasiswa.unesa.ac.i d/index.php/pensa/article/view/13 $42 / 990$

Lasmiyati, L., \& Harta, I. (2014). Pengembangan modul pembelajaran untuk meningkatkan pemahaman konsep dan minat SMP. Jurnal Pendidikan Matematika, 9(2), 161174. https://doi.org/10.21831/pg. v9i2.9077

Lesser, L. M. (2011a). Making statistics memorable: New mnemonics and motivations. Section on Statistical Education-JSM, 1118-1124. Retrieved from https://www. researchgate.net/publication/26799 0353_Making_Statistics_Memorable _New_Mnemonics_and_Motivations

Lesser, L. M. (2011b). On the use of mnemonics for teaching statistics. Model Assisted Statistics and Applications, 6(2), 151-160. https://doi.org/10.3233/MAS-20110183

Mocko, M., Lesser, L. M., Wagler, A. E., \& Francis, W. S. (2017). Assessing effectiveness of mnemonics for tertiary students in a hybrid introductory statistics course. Journal of Statistics, 25(1), 2-11. https://doi.org/10.1080/10691898. 2017.1294879

Muflikhati, I., Hartoyo, H., Sumarwan, U., Fahrudin, A., \& Puspitawati, H. (2010). Kondisi sosial ekonomi dan tingkat kesejahteraan keluarga: Kasus di wilayah Pesisir Jawa Barat. Jurnal Ilmu Keluarga Dan Konsumen, 3(1), 1-10. https://doi. org/10.24156/jikk.2010.3.1.1

Putri, A. E., Ramli, M., \& Suciati, S. (2017). Uji kelayakan modul animalia kontekstual berbasis level of inquiry untuk siswa SMA di wilayah pesisir. JURNAL BIOEDUKATIKA, 5(2), 3945. $\quad$ https://doi.org/10.26555/ bioedukatika.v5i2.6482

Saleh, A. R., Mustafa, B., Widiyanto, W., Kurniadi, D., Pongtuluran, W., \& Suryani, N. (2007). Pemetaan minat baca masyarakat di tiga provinsi: Sulawesi Selatan, Riau dan Kalimantan Selatan. https://doi. org/10.13140/RG.2.1.3103.7049

Tur, G., \& Marín, V. I. (2014). Enhancing learning with the social media: 
Student teachers' perceptions on Twitter in a debate activity. Journal of New Approaches in Educational Research, 4(1), 46-43. https://doi. org/10.7821/naer.2015.1.102

Vikagustanti, D. A., Sudarmin, S., \& Pamelasari, S. D. (2014). Pengembangan media pembelajaran monopoli IPA tema organisasi kehidupan sebagai sumber belajar untuk siswa SMP. Unnes Science Education Journal, 3(2), 452-559. Retrieved from https://journal. unnes.ac.id/sju/index.php/usej/arti cle/view/3330

Wasak, M. (2012). Keadaan sosial-ekonomi masyarakat nelayan di Desa Kinabuhutan Kecamatan Likupang Barat, Kabupaten Minahasa Utara, Sulawesi Utara. Pacific Journal, 1(7), 1339-1342. Retrieved from http://repo.unsrat.ac.id/280/
Widyaningrum, R., Sarwanto, S., \& Karyanto, P. (2013). Pengembangan modul berorientasi POE (Predict, Observe, Explain) berwawasan lingkungan pada materi pencemaran untuk meningkatkan hasil belajar siswa. Bioedukasi: Jurnal Pendidikan Biologi, 6(1), 100-117. https:// doi.org/10.20961/bioedukasi-uns. v6i1.3920

Wilson, K., Copeland Solas, E., \& GuthrieDixon, N. (2016). A Preliminary study on the use of mind mapping as a visual-learning strategy, in general Education Science classes for Arabic speakers in the United Arab Emirates. Journal of the Scholarship of Teaching and Learning, 16(1), 31-52. https://doi.org/10.14434/josotl.v16 i1.19181 